\title{
A panorama of the fossil algae: from cyanobacteria and calcimicrobes to the green calcareous algae
}

\author{
A tribute to Erik Flügel and the Erlangen School
}

\author{
Ioan I. Bucur • Franz T. Fürsich
}

Published online: 12 December 2012

(c) Springer-Verlag Berlin Heidelberg 2012

Initiated in the first half of the 19th century, investigations of calcareous algae flourished after the Second World War, in connection with the intensification of oil exploration in carbonate reservoirs. This field of research immediately provided a new micropaleontological tool for stratigraphic and paleoecological characterization of sedimentary strata. When a representative community working on fossil calcareous algae had become established by the 1970s and 1980s, such investigations reached a peak. This community gathered at specialized international meetings, where the top results were shared. The late Professor Erik Flügel was the one who organized the first international symposium on fossil algae in Erlangen in 1975. Eric Flügel was well known in the international scientific community for his studies on carbonate rocks, especially on fossil calcareous algae. More than that, he was widely appreciated for his exceptional mentoring qualities, from which numerous generations of students in this field benefited. At Erlangen, he founded the carbonate microfacies and calcareous algae school; in 1979 he initiated the journal Facies, currently one of the most prominent publications in the field. As a sign of our deep appreciation, we dedicate this volume to his memory.

The symposium organized in Erlangen represented the start of a quadrennial series of international reunions that successively took place in Paris (1979), Golden, Colorado (1983), Cardiff (1987), Capri (1991), Ankara (1995), Nanjing (1999), Granada (2003), Zagreb (2007), and Cluj-Napoca (2011). These scientific meetings encouraged the development of the study of calcareous algae, as well as international collaborations in the field. Accordingly, the

I. I. Bucur · F. T. Fürsich ( $\square)$

Erlangen, Germany

e-mail: franz.fuersich@gzn.uni-erlangen.de
International Fossil Algae Association (IFAA) decided to initiate an additional conference series, timed in-between the international meetings. The latter were defined as "regional meetings", being organized as fieldwork-based workshops. Nevertheless, they always had an international character, from the participants and topic point of view. The first regional IFAA symposium took place in Granada (1989), followed by the ones in Munich-Vienna (1993), Krakow (1997), Cluj-Napoca (2001), Ferrara (2005), and Milan (2009). In the last decades, the proceedings of these international and regional symposia summed up the state of the art in calcareous algae research. We hope that the current issue of Facies will continue this trend.

The current volume gathers some of the presentations given at the 10th International Symposium on Fossil Algae (Cluj-Napoca, September 2011), as well as some other recent results in the study of calcareous algae. The contributions cover a wide range of topics, from the study of some end-products of cyanobacteria and calcimicrobes to studies of red and dasycladalean green algae.

Basso et al. (2013) describe in their contribution the present-day formation of microbialites containing cyanobacteria, bacteria, and microalgae colonies in southern Sinai (Egypt). Based on macroscopic morphology, texture, and degree of lithification, four categories of microbialites were recognized. Their presence in the area is considered to result from the combination of local sedimentary dynamics and accommodation space in a peritidal tropical environment with high variations of temperature and salinity.

Various fossil microbialites associated with micro-encrusters are described by Pleş et al. (2013) from Upper Jurassic limestones in the Southern Carpathians (Romania). The deposits mainly consist of massif reef limestones including a variety of microbialites associated with micro-encrusters. The high abundance of dense micrite, the presence of 
laminated structures, of clotted, thrombolitic or peloidal microfabrics, of biogenic encrustations and cement crustsall represent the contribution of microbialites to the reef construction. Such bioconstructions, defined as "coralmicrobial-microencruster boundstones", are considered to represent important paleobiogeographic features.

Recently, the potential relationship of Lithocodium aggregatum to calcimicrobial structures has been debated intensely. In this volume, Cherchi and Schroeder (2013) revisit the type material stored in the British Museum (Natural History). Based on their results, L. aggregatum is considered as a calcimicrobial crust infested by boring sponges (ichnotaxon Entobia).

Another microorganism considered for decades as problematic, Bacinella, is studied by Schlagintweit and BoverArnal (2013) in Lower Aptian rocks of the western Maestrat Basin (Spain). The authors revise the genus Bacinella and the various associated species. Bacinella is interpreted as an excavating organism producing branched channels by perforating biogenic hardgrounds. The genus is assigned to the filamentous-septate endolithic algae of the Class Ulvophyceae. Also, the authors consider that almost all the currently reported occurrences of "Bacinella irregularis" should not be assigned to this taxon; instead, they represent vesicular crusts that should be defined as bacinellid fabrics.

In an extensive paper, Senowbari-Daryan (2013) investigates representatives of the genus Tubiphytes and of some similar organisms from Triassic reefs of the Tethys. The author emphasizes the differences between Paleozoic and Triassic Tubiphytes and describes the new taxa Tubiphytes carnicus, T. alcicornis, and Plexoramea cylindrica. Additionally, the new genus Carnyphytes is proposed, as well as two new combinations, Carniphytes multisiphonatus and Plexoramea gracilis.

Halysis, another organism with debated systematic assignment, is discussed by Frisch et al. (2013). The specimen-rich samples from Upper Ordovician rocks of South China allowed a detailed investigation. The authors offer a 3-D computer model of Halysis; virtual sections through the model could be compared with images obtained from actual thin-sections. As a result, this microfossil was reconstructed to consist of parallel, juxtaposed, and partly branched tubes.

In this volume, red algae are the object of a single study (Nebelsick et al. 2013). The authors have investigated Lower Oligocene limestones from Monti Berici (Southern Alps, Italy) in order to document paleoecological changes within a monotonous sedimentary succession. They recognized four carbonate facies types, in which red algae play a significant role. The Corallinaceae content is interpreted in relation to light intensity, hydrodynamic energy, biotic interactions, and substrate stability. The succession of facies suggests asymmetric sea-level changes with rapid regressions and gradual transgressions.
Dasycladalean algae are investigated in several papers that provide significant new paleontological results. Parvizi et al. (2013) describe an interesting association of calcareous algae and microproblematic organisms from the Zagros Mountains (SW Iran). Dasycladaleans dominate the associations; in addition, Gymnocodiaceae, phylloid algae, and microproblematic organisms were identified. The detailed analysis of Epimastoporaceae led to the emendation of the algal genera Epimastopora and Epimastoporella.

In their paper, Barattolo et al. (2013) provide a new description for Triploporella remesi, a dasycladalean alga described more than 100 years ago from Upper Jurassic deposits in the Western Carpathians. The study of the new specimens identified in the Kotouč quarry-the assumed type locality for the species erected by Steinmann in 1903 - not only adds significant details to the morphology, but also allowed re-assessing the development of the cyst containers within the lateral ramifications.

Representatives of the genus Triploporella from Lower Cretaceous rocks in Romania were studied by Bucur et al. (2013). The authors used this opportunity to review some species previously assigned by various authors to Triploporella; according to the current results, they should be either affiliated to other genera through new combinations, or excluded from the genus.

Until recently, dasycladalean algae from Middle Cretaceous deposits of South America were hardly known. In two papers in this volume, Granier et al. (2013a, b) provide some new data on this subject. In one of the papers a new genus, Brasiliporella, is introduced based on the study of a well-preserved specimen of former Holosporella nkossaensis, for which the new combination Brasiliporella nkossaensis is proposed. Moreover, the discussion on the systematic position of the taxon led to the introduction of two new families, Bornetellaceae and Thyrsoporellaceae. At the same time, the families Dasycladaceae and Triploporellaceae were emended. The second paper includes the description of a new species of Neomeris (Neomeris srivastavai), identified in the same deposits in Brazil. The description is followed by the subdivision of the genus Neomeris into three subgenera: N. (Neomeris), N. (Larvaria), and $N$. (Drimella).

Hosseini et al. (2013) propose another new dasycladalean genus, Iranella inopinata $\mathrm{n}$. gen., n. sp. This alga was originally described by Gollestaneh (1965) as Salpingoporella? inopinata. For the latter, Hosseini et al. provide a new description and interpretation based on the rich fossil material collected from the Zagros Mountains.

The Upper Cretaceous dasycladalean algae of the Lower Gosau Subgroup, Northern Calcareous Alps, are investigated by Schlagintweit et al. (2013a), who point out their similarity with the Upper Cretaceous dasycladalean flora of 
the peri-Adriatic area. The authors regard the scarcity of the association in the Alps as a distinctive feature.

Only a single contribution deals with Cenozoic dasycladaleans (Schlagintweit et al. 2013b). In the Upper Eocene rocks of the Swiss Alps the authors have identified extremely well preserved specimens of Clypeina helvetica. These allowed a more detailed description of the species, including biometric data and excellent microscopic images of thin-sections.

Finally, the importance of dasycladaleans for delimiting paleobiogeographic provinces is demonstrated in the paper by Taherpour et al. (2013). Based on the distribution of the dasycladalean species Kopetdagaria sphaerica and of the foraminifer Balkhania balkhanica, the authors define the Carpathian-Cimmerian paleogeographic province. Additionally, detailed stratigraphic and paleoecological information on these microfossils is provided.

In summary, the current volume provides a synthetic panorama on some of the most recent research directions and results concerning the study of calcareous algae. The numerous significant results offer new perspectives for future investigations.

Acknowledgments The guest editors are indebted to the following reviewers who helped to improve the manuscripts: Julio Aguirre, Filippo Barattolo, Davide Bassi, Markus Bertling, Juan Carlos Braga, Nicolas Carras, Marc A. Conrad, Pedro Cozar, Patrick Génot, Bruno Granier, Tonci Grgasovic, Yriu Iasufumi, Steven Kershaw, Boguslaw Kolodziej, Jochen Kuss, Alexandre Lethier, Jean-Pierre Masse, Jörn Peckmann, Brian Pratt, Rajka Radoicic, Joachim Reitner, Robert Riding, Felix Schlagintweit, Lucia Simone, Daniel Vachard, Rolf Warthmann, and Markus Wilmsen.

\section{References}

Barattolo F, Bucur II, Kołodziej B, Hoffmann M, Skupien P (2013) Triploporella remesi (Steinmann, 1903), dasycladalean green algae, from the Tithonian-Lower Berriasian of Štramberk (Czech Republic) revisited. Facies. doi:10.1007/s10347012-0343-z

Basso D, Bracchi VA, Favalli AN (2013) Microbialite formation in Southern Sinai (Egypt). Facies. doi:10.1007/s10347-012-0330-4

Bucur II, Bruchental C, Cociuba I, Granier B, Hebriştean AM, Lazar D-F, Marian AV, Săsăran E (2013) Representatives of the genus Triploporella (Dasycladales, calcareous algae) in the Lower Cretaceous limestones of Romania. Facies. doi:10.1007/s10347012-0334-0
Cherchi A, Schroeder R (2013) Revision of the holotype of Lithocodium aggregatum Elliott, 1956 (Lower Cretaceous, Iraq): new interpretation as sponge-calcimicrobe consortium. Facies. doi:10.1007/s10347-012-0336-y

Frisch K, Munnecke A, Schulbert C, Zhang Y (2013) Tubes or cell sheet? A 3-d reconstruction of Halysis Høeg, 1932 from the Upper Ordovician of south China. Facies. doi:10.1007/s10347012-0329-x

Granier B, Dias-Brito D, Bucur II (2013a) A new mid-Cretaceous Neomeris (dasycladacean alga) from the Potiguar Basin, Brazil. Facies. doi:10.1007/s10347-012-0322-4

Granier B, Dias-Brito D, Bucur II, Tibana P (2013b) Brasiliporella, a new mid-Cretaceous dasycladacean genus: the earliest record of the Tribe Batophoreae, Facies. doi:10.1007/s10347-012-0312-6

Hosseini S, Conrad MA, Kindler P (2013) Iranella inopinata Gollestaneh, 1965, a puzzling dasycladalean alga from the Lower Cretaceous shallow carbonate shelf deposits of the Zagros fold- thrust belt, SW Iran. Facies. doi:10.1007/s10347012-0324-2

Nebelsick JH, Bassi D, Lempp J (2013) Tracking palaeoenvironmental changes in coralline algal dominated carbonates of the Lower Oligocene Calcareniti di Castelgomberto formation (Monti Berici, Italy). Facies. doi:10.1007/s10347-012-0349-6

Parvizi T, Rashidi K, Vachard D (2013) Middle Permian calcareous algae and microproblematica (Dalan Formation, Dena Mountain, High Zagros, SW Iran). Facies. doi:10.1007/s10347-012-0357-6

Pleş G, Mircescu CV, Bucur II, Săsăran E (2013) Encrusting microorganisms and microbial structures in Upper Jurassic limestones from the Southern Carpathians (Romania). Facies. doi: 10.1007/s10347-012-0325-1

Schlagintweit F, Bover-Arnal T (2013) Remarks on Bacinella Radoičić, 1959 (type species B. irregularis) and its representatives. Facies. doi:10.1007/s10347-012-0309-1

Schlagintweit F, Sanders D, Studeny M (2013a) Dasycladaleans from the Upper Turonian to Santonian (Gosau Group pro parte) of Austria, and palaeobiogeographic considerations. Facies. doi: 10.1007/s10347-012-0316-2

Schlagintweit F, Bover-Arnal T, Menkveld-Gfeller U, Strasser A (2013b) Clypeina helvetica Morellet and Morellet, 1918, revisited. A Priabonian (Late Eocene) dasycladalean alga from the Diablerets Nappe of the Helvetic Alps, SW Switzerland. Facies. doi:10.1007/s10347-012-0311-7

Senowbari-Daryan B (2013) Tubiphytes Maslov, 1956 and description of similar organisms from Triassic reefs of the Tethys. Facies. doi:10.1007/s10347-012-0353-x

Taherpour KAM, Schlagintweit F, Vaziri SH, Aryaei AA, Ashouri AR (2013) Balkhania balkhanica Mamontova, 1966 (benthic foraminifera) and Kopetdagaria sphaerica Maslov, 1960 (dasycladalean alga) from the Lower Cretaceous Tirgan Formation of the Kopet Dagh mountain range (NE Iran) and their palaeobiogeographic significance. Facies. doi:10.1007/s10347012-0323-3 